\title{
Identifying Physic Concepts in Yarn Production by None Fortress Society, Tetaf Village
}

\author{
Demeryati Langtang ${ }^{1}$, Kostan D.F Mataubenu ${ }^{2}$ \\ Physics Program, Sekolah Tinggi Keguruan dan Ilmu Pendidikan (STKIP) Soe, Indonesia ${ }^{1,2}$ \\ yatilangtang02@gmail.com¹, kostan@stkip.ac.id ${ }^{2}$
}

Received: November $27^{\text {th }}, 2019$. Revised: January $30^{\text {th }}, 2020$. Accepted: January $31^{\text {th }}, 2020$

\author{
Keywords : \\ Physic Concepts Identification; \\ Local Wisdom
}

\begin{abstract}
Science learning is better related to nature through local wisdom since learners can gain more comprehension due to familiarity of occurring events through local wisdom based learning and they can preserve the local wisdom. This research aimed to identify physic concepts that occurred in the yarn processing using cotton by local society of None Fortress. The phenomenological design of qualitative research was undertaken in which the data triangulation technique comprised interviews, observation and documentation using an interview sheet, observation sheet and camera as instruments. The identification result of physic concepts in yarn production by None Fortress people covered Energy, Friction, Rotatory Motion, Circular Motion, Simple machine (Gear), Materials elasticity, vibration, measurement, capillarity, and radiation heat transfer. Based on the invented concepts, further research will expected to integrate the identification result in physic learning.
\end{abstract}

\section{INTRODUCTION}

Indonesian Archipelago consists of 32 provinces with their own customs. Indonesian culture affects development from time to time [1]. Along with information and technology progress in this globalization era, the relation and interconnectedness of world cultures grow higher [2]. According to Kamus Besar Bahasa Indonesia (KBBI), culture is human's whole knowledge as social being used to understand his surroundings and experiences which guides his behavior. Hence, it can be stated that knowledge is highly related to experience and realization gained from one' $\mathrm{s}$ culture.

Science is "knowledge gained from learning and demonstration" or "knowledge that covers a general truth of existing nature laws gained and demonstrated through scientific methods" [3]. Thus, to understand science well, learning should be linked to nature through events of daily life. Suastra [4] and Parmin [5] proposed that the upcoming science learning must be afforded to be balanced between science itself and scientific behaviors cultivation as well as local wisdom values that appear and develop within society. 
Science, particularly physic is known as a difficult, confusing, and unpleasant subject. This goes along interview results conducted by Mujadi [1] which was done to several junior and senior high school students in South Jakarta. They argued that physic was difficult, scary due to counting and formulas, confusing, and needed imagination. One of many offered solutions was to teach physic by relating material with the culture of the place learners resided. None Fortress is a cultural tourist destination in South Middle Timor Regency which offers many physic concepts to be identified and integrated in physic classrooms such as materials development, students' worksheet, handouts, test items and learning models. Thus, a research was carried out to identify physic concepts None Fortress people applied in producing yarn from cotton as the basic material for ikat woven.

Since the improvement of science and technology which result in the decrease or even extenction of the local wisdom. One of the example of the local wisdom extenction is the proccess of thread from original cotton in None Fortress (Benteng None) in Timor Middle South (TTS) regency. Nowdays, children in TTS regency do not know where does the yarn come from which then designed to be a piece of weaving (blanket or other kinds). Therefore, in order to maintain the local wisdom which is really valuable for the society, the lesson of local wisdom need to be included in teaching and learning process especially in Physics lesson. This study indentified the Physiscs concepts on the process of cotton as the basic materials of weaving of Benteng None society and from the identification result will be integrated to be the Physics learning materials which is local wisdom based for students in grade eight (VIII) in Junior High School especially for the materilas in relation to simple plane or energy. Physics concepts integration in the form of learning materials local wisdom based in Hulu Sungai regency can improve students' learning achievement based on research by Hartini, et al [6] and it also could help to optimalized the students' sanggam character as shown in research by Oktaviana,et al [7].

\section{METHOD}

This was a phenomenological model of qualitative research design since the researcher wanted to obtain observation and interview data from yarn makers in None Fortress. The primary data from both techniques were analyzed to identify physics concepts during the procedure of yarn making by the community of None Fortress. The concept map of this study is pictured in Figure 1.

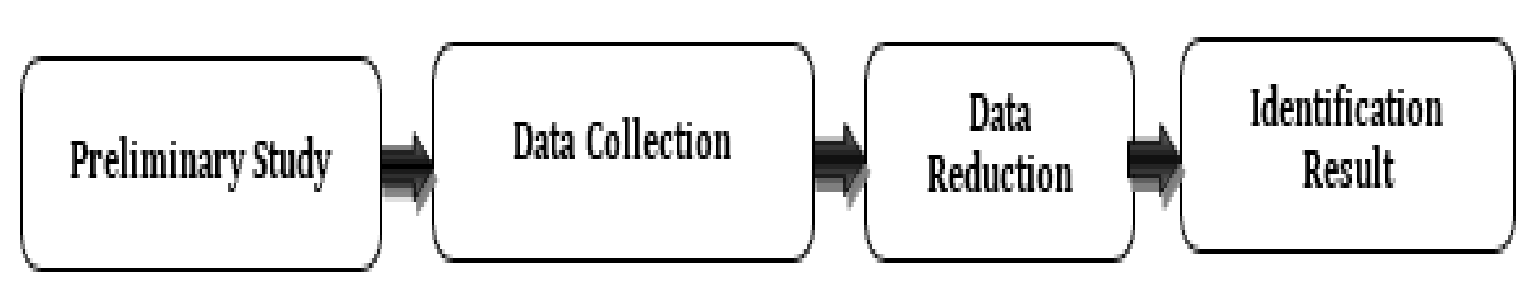

Figure 1. Research Design of Physic Concepts Identification in Yarn Production

A man as group chief and four ladies of None Fortress folks were chosen as research samples. This research was conducted for three months from May end to September 2019 in None Fortress, Tetaf Village, South Middle Timor Regency.

Initial observation was undertaken in preliminary study to determine things needed for this study. Then, researchers went to study context and started collecting data using data triangulation technique which were observation, interview, and documentation [8]. The researchers were directly involved in yarn making from first stage to last stage during data collection so it was participatory observation and semistructured interview.

During the study, researchers had been informed about cotton based yarn making handicraft by None 
Fortress folks, so direct involvement was done to collect comprehensive data. The obtained data were reduced by selecting appropriate data related to physics concepts invented during yarn making. Then data were presented and drawn into conclusion of physics concepts found in cotton based yarn production so they could be implemented into physics learning by other researchers.

\section{RESULTS AND DISCUSSIONS}

Cotton is a substance used as basic material to produce yarn which will be used to produce fabrics to make clothes, bags, and other typical stuffs. Cotton is used as the main material in yarn production due to its good fiber. Cotton has $7 \%$ of elasticity therefore it is easy to be shaped compared to other materials [9]. Some produce yarn from cotton using machine and some used the traditional methods. People in None Fortress still applied the traditional method which was inherited from their ancestors. Yarn they made was used to produce ikat woven of a particular tribe in South Middle Timor. The stages of producing yarn begun by separating cotton from its seeds then proceeded to yarn compressing, smoothing, rolling, spinning, and dying. The stages are shown in Table 1.

Table 1. Stages of Yarn Production

\begin{tabular}{|c|c|c|}
\hline Stages & Description & Physic Concepts Identification \\
\hline $\begin{array}{l}\text { Stage I } \\
\text { Separating } \\
\text { Cotton from } \\
\text { its seeds } \\
\text { (Katas) }\end{array}$ & $\begin{array}{l}\text { In this stage, cotton } \\
\text { was peeled off from its } \\
\text { seed manually. }\end{array}$ & $\begin{array}{l}\text { Identified physic concepts in this } \\
\text { stage were: The Pressure of hands so } \\
\text { seeds can be released from cotton. } \\
\text { Friction between fingers surface with } \\
\text { cotton and seeds. }\end{array}$ \\
\hline
\end{tabular}

Stage II

Cotton

Pressing

(Bninis)

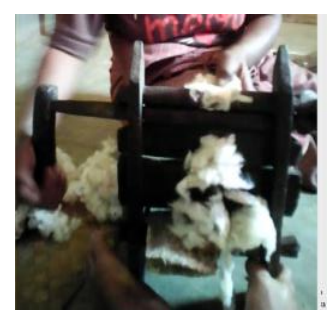

After separating seeds from cotton, yarns will be pressed (Bninis). This stage is done using pressing machine or bninis. Cotton is placed between two round

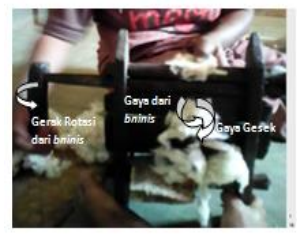
logs of bninis then bninis is moved in round motion to produce cotton flakes.
This stage depicts the following physic concepts:

The Friction which occurs when there is a meeting point between cotton surface and bninis.

Rotatory motion. That is a motion of bninis circles its axis when it is turned around.

Gear. It can be seen from the tip of two logs which have different gear position on the upper left of bninis which is meant to settle bninis' turning pace as needed. Energy can change form as shown by different form of cotton before and after pressed in bninis. 


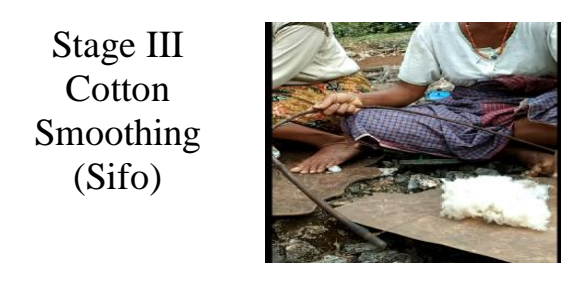

The pressed cotton is then smoothed using sifo. Sifo is a tool formed like a bow made of bamboo or small wood tied using a rope. In this stage, cotton flakes are placed on the rope of sifo. The rope will be twitched so clods of cotton flakes dissolve into refined form.
In the cotton smoothing phase using sifo, there was material's elastic nature which was found in rope and bamboo.

Vibration. There was vibration when the rope of sifo was twitched.
Stage IV

Cotton

Rolling

Process

(Nunut)

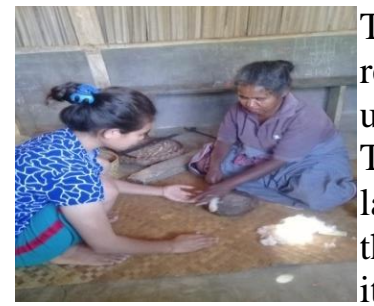

The next is to roll refined cotton (Nunut) using a bamboo stick. The refined cotton is laid on a flat stone, then a bamboo stick on its top to roll cotton.
In nunut process there was friction of the physic concept which occurred between hands' surface with cotton and cotton layer with stone.

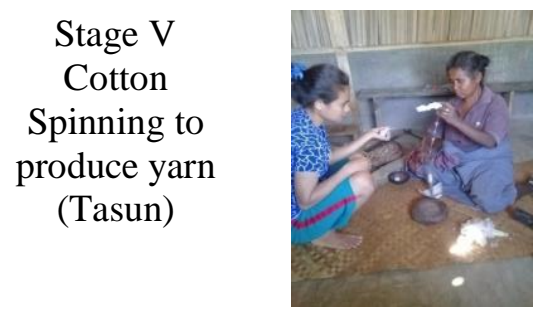

Stage V

\section{Cotton}

Spinning to

produce yarn

(Tasun)
Tasun is the following stage after Nunut. It is a process of spinning cotton into yarn. Rolls of cotton are placed on a log that has small and a bit sharp tip which functions as an axis to turn cotton during the spinning stage. 10 rolls of cotton from nunut are needed in this phase to get a big roll of yarn.
Several physic concepts found in tasun stage were:

The friction which occurred when the surface of Ike (wood used to roll cotton which will be spun) met with a plate or coconut shell. Circular motion existed when Ike was turned in rounds to spin cotton. Materials elasticity was shown as the spun cotton tore apart if it was spun in strong pull. It is because of more energy given that exceeds cotton's elasticity limit. The energy causes form changing which happened when cotton was put on Ike and was given a pull, the initial clods of cotton slowly turned into a thinner form which finally became yarn.

\section{Stage VI \\ Yarn Organizing (Aunut)}

The yarn earned from cotton spinning will be rolled on a stone or wood to avoid disarray. The rolled yarn is then none on an object to measure its length.
In Aunut stage, the identified physic concept was:

Circular motion in which the people rolled yarn on stone or wood. The friction which occurred between fingers and yarn during rolling the yarns. 


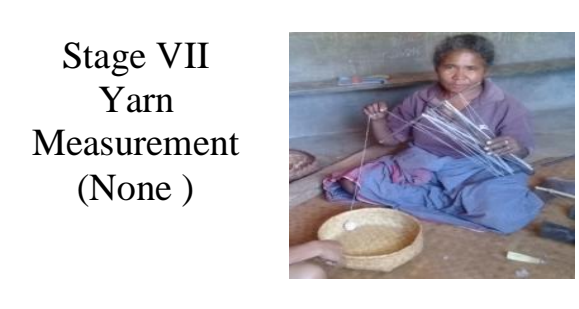

After being organized, yarns surfaces using none (a piece of wood equipment to measure yarn's length).
The physic concept in this stage was measurement. The measurement stage employed measuring equipment with an irregular unit that was to get an ikat woven scarf, it took yarn with two spans of mature man length and 200 strands of yarn.

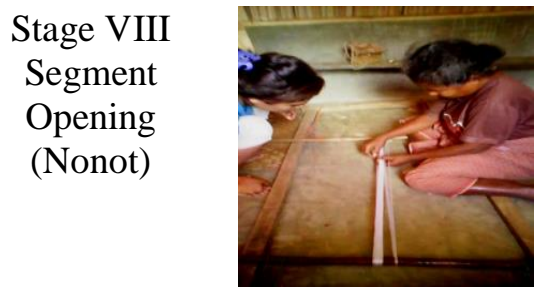

Yarns are then settled on silak to open their segments so they can be easily formed during the tying process.
This stage revealed following physic concept:

Elasticity which happened during yarn settling and tying. If yarns were tied too strong and tight, they would be broken because it went beyond their elastic limit.

The energy which was shown by pulling strength hands gave while settling yarns on silak.
Stage IX Tying/

Pattern

Forming

(Futus)

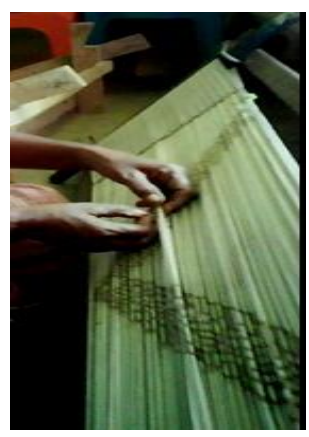

The opened yarns are then tied using ropes of Corypha plant (tain tusi) in which this tying process form pattern wanted by the weaver. The amount of yarn used during this stage to form a pattern is not counted but taken as the weaver wants until a pattern is formed.
The physic concept that occurred in this stage was tensile strength when the weaver tied yarn using Corypha to form a pattern.

\section{Stage X \\ Dying \\ Process \\ (Lepat)}

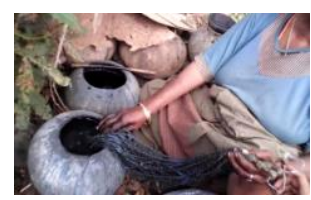

The next undertaken procedure is to plunge patterned yarn to get the expected color. The yarns are plunged into a mixture of indigofera leaves, whiting and water in a crock.
Lepat stage covered the following physic concepts:

Dissolution of solid-liquid substances in which the difference of tensile strength between molecular caused solid substance having limited dissolution in a dissolver. The intermolecular tensile strength in solid substance was higher than in liquid. Capillarity marked by the elevation of whiting + indigofera leaves + water solvent. 


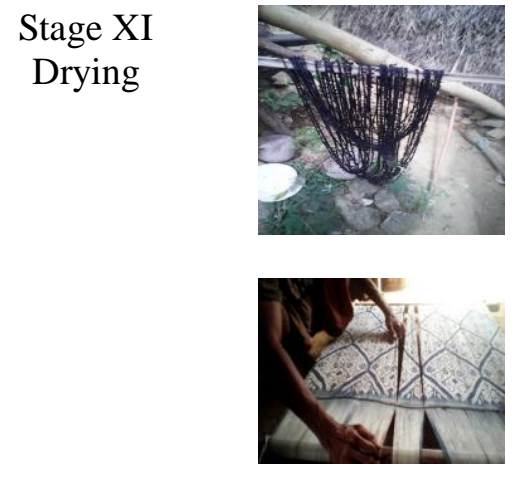

The plunged yarns will finally be dried up. This phase takes a full sunny day but takes 2 3 days on rainy days to fully dry. Before being dried, the yarns are split to quicken the procedure. When they dry, those yarns are split again to ease the weaving process. The dyed yarns produced from cotton which have had patterns can be woven to become an ikat woven.
Physic concepts identified in this last stage was:

Radiation heat transfer in which the plunged yarns were directly dried under sunlight.

Evaporation. This happened as the weaver split clods of plunged yarn to help them dry.

The result of the study from the Physics concepts identification on thread process from cotton by the societies of Benteng None (None Fortress) could be integrated in physics learning that could protect the local wisdom. This result was in line with research by Rusilowati, et al which stated that learning process which is local wisdom based should be implemented because it could make the students to understand the materials easier and students also understand the local wisdom in a place that could avoid the extinction [10].

The result of physics concept on local wisdom of Benteng None (None Fortress) society which is the process of cotton to be thread or yarn could be integrated in the form of learning materials, questions, students work sheet (LKS), learning modul, and learning model local wisdom based in order to be used for the process of teaching and learning in the classroom. By doing this way (local wisdom integration in learning) could improves students' critical thinking and science ability process as argued by Dewi, et al [11]. On th other hand, Martawijaya stated that the integration of learning materials which is local wisdom based could improve students' scientific character [12]. Some of these studies showed that there is an integration of local wisdom in learning process [12].

\section{CONCLUSION AND SUGGESTION}

One of the preserved cultures is presented by people of None Fortress in South Middle Timor on yarn production from cotton material to weave traditional ikat woven which contains a big amount of physic concepts. The study exposed several physic concepts including Energy, Friction, Rotatory Motion, Circular Motion, Simple Machine (Gear), Materials Elasticity, vibration, measurement, capillarity, and radiation heat transfer. It was expected that the result of this study encouraged other researchers to explore identification result of physics concepts in science and physics in forms of learning materials, handouts, students' worksheet, and evaluation instruments.

\section{ACKNOWLEDGMENTS}

We would like to express our deepest gratitude to STKIP SoE which has supported us and provided us the opportunity to carry out this study. We would also like to thank Kemenristek Dikti which granted us Funding for Beginner Lecturers Research that helped us throughout this study. Sincere gratitude also 
goes to our two students (Yorince Atto and Marselina Ivon) who have helped us during the study. May God bless us to do all our responsibilities and works.

\section{REFERENCES}

[1] Mujadi. (2015). Indiginasi Seni dan Budaya dalam Pembelajaran Fisika. JRKPF (Jurnal Riset dan Kajian Pendidikan Fisika), 2(2): 66-72.

[2] Rai, S. I. A. (2013, September). Pendidikan sains berlandaskan budaya lokal tri kaya parisudha. In PROSIDING: Seminar Nasional Fisika dan Pendidikan Fisika (Vol. 4, No. 1).

[3] Khusniati, M. (2014). Model pembelajaran sains berbasis kearifan lokal dalam menumbuhkan karakter konservasi. Indonesian Journal of Conservation, 3(1).

[4] Suastra, I. W. (2010). Model Pembelajaran Sains Berbasis Budaya Lokal Untuk Mengembangkan Potensi Dasar Sains dan Nilai Kearifan Lokal di SMP. Jurnal Pendidikan dan Pengajaran, 43(1).

[5] Parmin, Sajidan, Ashadi, \& Sutikno. (2017). Etnosains: Kemandirian Kerja Ilmiah dalam Merekonstruksi Pengetahuan Asli Masyarakat menjadi Pengetahuan Ilmiah. Semarang: CV.Swadaya Manunggal.

[6] Hartini, S., Misbah, M., \& Resy, R. (2017). Pengembangan Modul Fisika Berintegrasi Kearifan Lokal Hulu Sungai Selatan. Jurnal Inovasi Dan Pembelajaran Fisika, 4(2): 157-162.

[7] Oktaviana, D., Hartini, S., \& Misbah, M. (2017). Pengembangan Modul Fisika Berintegrasi Kearifan Lokal Membuat Minyak Lala Untuk Melatih Karakter Sanggam. Berkala Ilmiah Pendidikan Fisika, 5(3): 272-285.

[8] Sugiyono. (2018). Metode Penelitian Kombinasi (Mixed Methods). Bandung: Alfabeta.

[9] Siregar, Y., \& Eriningsih, R. (2011). Kain Rajut Kapas Dengan Sisipan Benang Karbon Untuk Keperluan Tekstil Teknik Tahan Api. Arena Tekstil, 26(2).

[10] Rusilowati, A., Supriyadi, S., \& Widiyatmoko, A. (2015). Pembelajaran Kebencanaan Alam Bervisi SETS Terintegrasi dalam Mata Pelajaran Fisika Berbasis Kearifan Lokal. Jurnal Pendidikan Fisika Indonesia, 11(1): 42-48.

[11] Dewi, N. P. S. R., Wibawa, I. M. C., \& Devi, N. L. P. L. (2017). Kemampuan berpikir kritis dan keterampilan proses dalam pembelajaran siklus belajar 7e berbasis kearifan lokal. JPI (Jurnal Pendidikan Indonesia), 6(1): 125-133.

[12] Martawijaya, M. A. (2015). Pengembangan Model Pembelajaran Fisika Untuk Meningkatkan Karakter Ilmiah Siswa SMP. Journal of Educational Science and Technology (EST), 1(1), 55-63. 